\title{
Hukum Pengangkatan Anak Melalui Akta Pengakuan Pengangkatan Anak Yang Dibuat Oleh Notaris
}

\author{
Teddy Prima Anggriawan \\ Fakultas Hukum, Universitas Airlangga \\ J1. Dharmawangsa Dalam Selatan, Kec. Gubeng, Surabaya \\ teddyhukum@gmail.com
}

\begin{abstract}
Abstrak
Penelitian ini bertujuan untuk meneliti permasalahan terkait dengan hukum pengangkatan anak melalui Akta pengakuan pengangkatan anak yang dibuat oleh Notaris dan mengetahui akibat hukum pengangkatan anak bagi pihak yang tidak memenuhi kewajiban sesuai perjanjian. Penelitian ini menggunakan metode yuridis normatif yang menggunakan sumber yang diperoleh dari Peraturan perundang-undangan, literatur dan karya tulis ilmiah. Analisa data yang digunakan adalah menggunakan deskriptif analitis yaitu metode yang menggunakan analisis terhadap peraturan perundang-undangan yang berlaku. Hasil penelitian ini dapat disimpulkan pada dasarnya pengangkatan anak harus dengan penetapan Pengadilan, hal tersebut didasarkan pada surat edaran mahkamah agung tanggal 7 April 1979 No. 2 tahun 1979 tentang Pengangkatan Anak dikatakan antara lain bahwa pengesahan pengangkatan anak warga negara Indonesia hanya dapat dilakukan dengan suatu penetapan di Pengadilan negeri, dan tidak dibenarkan apabila pengangkatan anak tersebut dilakukan dengan Akta yang dilegalisir oleh Pengadilan negeri. Sehingga dengan demikian, kasus pengangkatan anak harus melalui penetapan Pengadilan negeri dan Akta yang dibuat dihadapan notaris terkait dengan pengakuan anak hanya bersifat pengikatan terhadap apa yang dikehendaki para pihak secara privat terkait hubungan hukum masing-masing pihak tersebut terhadap pengangkatan anak dan tidak memiliki kekuatan hukum mutlak terkait dengan legalitas status pengangkatan anak tersebut jika tidak didaftarkan dan mendapat penetapan Pengadilan negeri.
\end{abstract}

Kata kunci: Pengangkatan Anak, Akta Pengakuan Anak, Notaris

\begin{abstract}
This study aims to examine problems related to the law of adoption through the Notary's acknowledgment of adoption and to find out the legal consequences of adoption for parties who do not fulfill their obligations according to the agreement. This study uses a normative juridical method that uses sources obtained from statutory regulations, literature and scientific papers. The data analysis used is descriptive analytical method that uses analysis of the prevailing laws and regulations. The results of this study can be concluded that basically the adoption of children must be based on the Court's decision, this is based on the Supreme Court circular letter dated April 7, 1979 No. 2 of 1979 concerning Adoption of Children, it is said, among other things, that the ratification of the adoption of children of Indonesian citizens can only be carried out by means of an order in a district court, and it is not justified if the adoption of the child is carried out with a deed legalized by the district court. Thus, cases of adoption must go through the determination of the district court and deeds made before a notary regarding the recognition of children are only binding on what the parties want privately regarding the legal relationship of each party to adoption and do not have absolute legal force. related to the legality of the status of adoption if the child is not registered and has been ruled by a district court.
\end{abstract}

Keywords: adoption, recognition of the Child, Notary

\section{A. Pendahuluan}

Manusia sebagai makhluk sosial memiliki naluri untuk saling berpasang-pasangan, dengan naluri tersebut manusia menginginkan sebuah komunitas kecil yaitu keluarga, sehingga manusia harus melangsungkan sebuah perkawinan untuk membentuk komunitas tersebut.

Menurut Pasal 1 ayat (2) Undang-undang Nomor 1 Tahun 1974 tentang Perkawinan, perkawinan adalah ikatan lahir dan batin antara seorang pria dengan seorang 
wanita sebagai suami isteri dengan tujuan membentuk keluarga (rumah tangga) yang bahagia dan kekal berdasarkan Ketuhanan Yang Maha Esa.

Setiap manusia yang memutuskan untuk melaksanakan perkawinan pada umumnya bertujuan membentuk keluarga yang bahagia dan kekal berdasarkan Ketuhanan Yang Maha Esa. Perkawinan juga bertujuan untuk mendapatkan seorang anak atau keturunan yang sah untuk melanjutkan garis keturunannya. Anak menurut alam pikiran sehat orang berakal adalah buah hati yang dinantikan oleh orang tuanya untuk meneruskan keturunan, mengikat dan melampiaskan curahan kasih sayang manusiawi nya. ${ }^{1}$ Dengan kehadiran anak sebagai penerus garis keturunan akan diharapkan dapat menambah kebahagiaan pasangan suami isteri dalam keluarga kecilnya. Alasan memperoleh keturunan ini yang sering dijadikan alasan utama mengapa seorang pria dengan seorang wanita memutuskan untuk membentuk keluarga. Meskipun memperoleh keturunan bukanlah satu-satunya alasan membentuk perkawinan namun pada kenyataannya ketidakhadiran seorang anak menjadi alasan ketidak sempurnaan sebuah keluarga, dan sering menjadi alasan putusnya sebuah perkawinan. Untuk mencegah putusnya perkawinan karena ketidakhadiran keturunan, maka dilakukanlah pengangkatan anak.

Di Indonesia pengangkatan anak bukanlah hal yang baru karena telah banyak pasangan suami istri yang melakukan pengangkatan anak dengan cara dan motivasi yang berbeda-beda. Pengertian Anak Angkat dalam Peraturan Pemerintah Republik Indonesia Nomor 54 tahun 2007 tentang Pelaksanaan Pengangkatan Anak adalah anak yang haknya dialihkan dari lingkungan kekuasaan keluarga orang tua, wali yang sah, atau orang lain yang bertanggung jawab atas perawatan, pendidikan, dan membesarkan anak tersebut, ke dalam lingkungan keluarga orangtua angkatnya berdasarkan keputusan atau penetapan Pengadilan. Dan dalam Pasal 1 ayat (2) Peraturan Pemerintah Republik Indonesia Nomor 54 Tahun 2007 tentang Pelaksanaan Pengangkatan Anak disebutkan bahwa "Pengangkatan Anak adalah suatu perbuatan hukum yang mengalihkan seorang anak dari lingkungan kekuasaan orangtua, wali yang sah atau orang lain yang bertanggung jawab atas perawatan, pendidikan dan membesarkan anak tersebut ke dalam lingkungan keluarga orangtua angkat".Mengenai pengangkatan anak di dalam Undang-Undang No. 23 Tahun 2002 tentang Perlindungan Anak yang dinyatakan dalam Pasal 40 ayat (1) mewajibkan orang tua angkat untuk memberitahukan tentang asal usul si anak dan orang tua

\footnotetext{
${ }^{1}$ Lulik Djatikumoro, Hukum Pengangkatan Anak Di Indonesia, Bandung : PT.Citra Aditya Bakti,2011, hal 
kandungnya. Selain itu di dalam Pasal 39 ayat (2) dinyatakan pengangkatan anak tidak memutuskan hubungan darah antara anak yang diangkat dan orang tua kandungnya. Pengangkatan anak hanya dapat dilakukan untuk kepentingan yang terbaik bagi anak. Demikian prinsip dari pengangkatan anak yang digariskan dalam Pasal 39 ayat (1) UndangUndang No. 23 Tahun 2002 Tentang Perlindungan anak. Akan tetapi dalam prakteknya tidak jarang hak-hak anak terenggut hanya karena pengangkatan anak itu dilakukan demi kepentingan orang tua.

Seperti kasus Kematian seorang anak angkat yang baru saja terjadi di Indonesia. Seorang anak bernama Angeline telah di adopsi oleh Margrieth Christina Megawe. Angeline telah di adopsi dari orang tua kandungnya sejak ia berusia 5 hari. Margarieth melakukan perjanjian atas pengangkatan Angeline di hadapan Notaris bersama dengan orang tua kandung Angeline. Orang tua kandung Angeline memberikan hak asuh Angeline kepada Margareith dengan alasan agar hidup Angeline lebih baik dikarenakan orang tua kandungnya tidak mampu untuk membiayai kehidupan Angeline. Di hadapan Notaris Margareith meminta untuk dibuatkan perjanjian hitam di atas putih sehingga lahirlah Akta pengakuan pengangkatan anak Nomor 18 tanggal 24 Mei 2007.

Didalam Pasal perjanjian tersebut tertulis bahwa Margareith akan menganggap Angeline sebagai anaknya sendiri dan memberikan hak-hak penuh kepada Angeline sebagai anak nya sendiri. Pihak Notaris telah menjelaskan kepada Margareith dan orang tua Angeline bahwa pengangkatan anak harus lah dilakukan di Pengadilan namun Margareith mengaku ini hanya perjanjian antara dirinya dan orang tua kandung Angeline saja. Pada tanggal 16 Mei 2015 Angeline dikabarkan hilang dan pada tanggal 10 Juni 2015 Angeline ditemukan tewas di halaman rumah Margareith. Dari kasus pengangkatan anak yang dilakukan Margareith di hadapan Notaris ini lah maka penulis tertarik untuk melakukan penelitian terkait dengan pengangkatan anak melalui Akta pengakuan pengangkatan anak yang dibuat oleh Notaris.

\section{B. Telaah Konsep}

Pengertian anak angkat berdasarkan Pasal 171 huruf (h) Kompilasi Hukum Islam, anak angkat adalah anak yang dalam hal pemeliharaan untuk hidupnya sehari-hari, biaya pendidikan, dan sebagainya beralih tanggung jawabnya dari orang tua asal kepada orang tua angkatnya berdasarkan putusan Pengadilan. 
Anak Angkat menurut UU Perlindungan Anak adalah anak yang haknya dialihkan dari lingkungan kekuasaan keluarga orang tua, wali yang sah, atau orang lain yang bertanggung jawab atas perawatan, pendidikan, dan pembesaran anak tersebut ke lingkungan keluarga orang tua angkatnya berdasarkan putusan atau penetapan Pengadilan. $^{2}$

Menurut Hilman Hadi Kusuma, dalam bukunya "Hukum Perkawinan Adat" anak angkat adalah anak orang lain yang dianggap anak sendiri oleh orang tua angkat dengan resmi menurut hukum adat setempat, dikarenakan tujuan untuk kelangsungan keturunan dan atau pemeliharaan atas harta kekayaan rumah tangga. ${ }^{3}$

Kemudian Dr.Mahmud Syaltut, seperti yang dikutip secara ringkas oleh Fatchur Rahman dalam bukunya Ilmu waris, membedakan dua macam arti anak angkat, yaitu :

Pertama; penyatuan seseorang terhadap anak yang diketahuinya bahwa ia sebagai anak orang lain kedalam keluarganya. Ia diperlakukan sebagai anak dalam segi kecintaan,pemberian nafkah,pendidikan dan pelayanan dalam segala kebutuhannya, bukan diperlakukan sebagai anak nasab nya sendiri.

Kedua; yakni yang dipahamkan dari perkataan “tabanni”(mengangkat anak secara mutlak). Menurut syariat adat dan kebiasaan yang berlaku pada manusia. Tabanni ialah memasukkan anak yang diketahuinya sebagai orang lain ke dalam keluarganya, yang tidak ada pertalian nasab kepada dirinya, sebagai anak yang sah, tetapi mempunyai hak dan ketentuan hukum sebagai anak. ${ }^{4}$

Dari segi etimologi yaitu asal usul kata adopsi berasal dari kata 'adoptie' bahasa Belanda, atau 'adopt' (adoption) bahasa inggris, yang berarti pengangkatan anak, mengangkat anak. Dalam bahasa Arab disebut 'tabbani' yang menurut Prof. Mahmud Yunus diartikan dengan 'mengambil anak angkat'. Sedangkan dalam Kamus Munjid diartikan 'ittikhadzahu ibnan', yaitu menjadikannya sebagai anak.

Pengertian dalam bahasa Belanda menurut Kamus Hukum, berarti 'Pengangkatan seorang anak untuk sebagai anak kandungnya sendiri.' Jadi di sini penekannya pada persamaan status anak angkat dari hasil pengangkatan anak sebagai anak

\footnotetext{
${ }^{2}$ Rusli Pandika, Hukum Pengangkatan Anak, Jakarta : Sinar Grafika, 2012, hal 106 ${ }^{3}$ Muderis Zaini, Adopsi Suatu Tinjauan Dari Tiga Sistem Hukum, Jakarta: Sinar Grafika, 2006, hal 5 ${ }^{4}$ Ibid
} 
kandung. Ini adalah pengertian secara literlijk, yaitu (adopsi) diover ke dalam bahasa Indonesia berarti anak angkat atau mengangkat anak. ${ }^{5}$

\section{Secara Terminologi}

Dalam Ensiklopedia Umum disebutkan bahwa adopsi adalah suatu cara untuk mengadakan hubungan antara orang tua dan anak yang diatur dalam pengaturan perundang-undangan. Biasanya adopsi dilaksanakan untuk mendapatkan pewaris atau untuk mendapatkan anak bagi orang tua yang tidak beranak. Akibat dari adopsi yang demikian itu ialah bahwa anak yang diadopsi kemudian memiliki status sebagai anak kandung yang sah dengan segala hak dan kewajiban. Sebelum melaksanakan adopsi itu calon orang tua harus memenuhi syarat untuk benar-benar dapat menjamin kesejahteraan bagi anak. ${ }^{6}$

Pengertian adopsi atau anak angkat adalah perbuatan mengangkat atau memungut anak orang lain untuk dijadikan sebagai anak atau dimasukkan kedalam anggota keluarga sedemikian sehingga mengakibatkan orang yang mengangkat atau memungut anak dengan anak yang diangkat atau dipungut timbul suatu hukum kekeluargaan yang sama seperti orang tua dengan anak kandungnya sendiri. ${ }^{7} \mathrm{R}$.Soepomo memberikan rumusan terhadap adopsi, bahwa adopsi adalah mengangkat anak orang lain sebagai anak sendiri. ${ }^{8}$

Seorang sarjana hukum Belanda yang khusus mempelajari tentang adopsi,yaitu J.A.Nota, memberikan rumusan bahwa adopsi adalah suatu lembagahukum (een rechtsinstelling), melalui mana seorang berpindah ke dalam ikatan keluarga yang lain (baru),dan sedemikian rupa sehingga menimbulkan secara keseluruhan atau sebagian hubungan-hubungan hukum yang sama seperti antara seorang anak yang dilahirkan sah dengan orang tua nya. ${ }^{9}$

Menurut Surojo Wignjodipuro Adopsi (mengangkat anak) adalah suatu perbuatan pengambilan anak orang lain ke dalam keluarga sendiri sedemikian rupa,sehingga antara orang yang memungut anak dan anak yang dipunggut itu timbul suatu hukum kekeluargaan yang sama. ${ }^{10}$

\footnotetext{
${ }^{5}$ Muderis Zaini, Op.cit, hal 4

${ }^{6}$ Ibid

${ }^{7}$ Dzulkifli dan Utsman, Kamus Hukum, Jakarta : Quantum Media Press, 2010, hal 13

${ }^{8}$ Djaja.S.Meliala, Pengangkatan Anak (Adopsi) di Indonesia, Bandung : Tarsito,1982, hal 3

${ }^{9}$ Ibid

${ }^{10}$ Muderis Zaini, Op Cit, hal 5
} 
Lewat surat edaran Mahkamah Agung No. 6 Tahun 1983, maka diatur mengenai tata cara adopsi anak. Motivasi merupakan unsur pertama yang perlu ditinjau bagi keluarga yang ingin mengadopsi anak, tentunya unsur ini kelak berkaitan dengan kewajiban si orang tua angkat untuk kelanjutan masa depan anak itu sendiri. ${ }^{11}$

Prosedur Pengangkatan Anak :

a) Adapun proses minimal yang harus dijalankan oleh calon orang tua angkat adalah surat pernyataan orang tua ketika menyerahkan anak. Namun jika calon anak angkat yang berasal dari panti asuhan maka Yayasan harus mempunyai surat izin tertulis dari menteri sosial yang menyatakan bahwa yayasan tersebut telah di izinkan bergerak di bidang kegiatan pengangkatan anak.

b) Calon orang tua angkat kemudian mengajukan permohonan ke Pengadilan Negeri, calon anak angkat juga harus mendapat izin tertulis dari Menteri Sosial / Pejabat yang di tunjuk. Setelah permohonan itu diterima Pengadilan Negeri, akan segera dilakukan pemeriksaan.

c) Pemeriksaan Tahap Pertama : Pengadian mendengar langsung saksi-saksi. calon orang tua angkat, orang tua kandung, badan atau yayasan sosial yang telah mendapat izin dari pemerintah disini yaitu Departemen Sosial, seorang petugas / pejabat instansi sosial setempat, calon anak angkat (jika dia sudah bisa di ajak bicara) dan pihak Kepolisian setempat (Polri).

d) Pemeriksaan Tahap Kedua : Pengadilan memeriksa bukti-bukti berupa surat-surat resmi, akte kelahiran / akte kenal lahir yang di tanda tangani oleh walikota atau bupati setempat, surat resmi pejabat lainya, akte notaris dan surat-surat di bawah tangan (korespondensi), surat-surat keterangan, pernyataan-pernyataan dan surat keterangan dari kepolisian tentang calon orang tua angkat dan anak angkat. Sebelum dikeluarkan penetapan sebagai jawaban dari permohonan adopsi, Pengadilan memeriksa dalam persidangan tentang latar belakang motif kedua belah pihak (pihak yang melepas dan pihak yang menerima anak angkat).

e) Tahap Akhir: Berupa penjelasan hakim tentang akibat hukum yang di timbulkan setelah melepas dan mengangkat calon anak angkat. Sebelum memberikan penetapan hakim memeriksa keadaan ekonomi, kerukunan, keserasian kehidupan keluarga serta cara mendidik orang tua angkat. Kira-kira tiga sampai empat bulan proses penetapan

\footnotetext{
${ }^{11}$ http://www.dinsos.lhokseumawekota.go.id/index.php/our-capabilities/88-tata-cara- angkat-anak-asuh, diakses pada hari Jum'at tanggal 9 September 2015, 15:10 Wib
} 
status anak adopsi / anak angkat itu selesai. Penetapan itu disertai akte kelahiran pengganti yang menyebutkan status anak sebagai anak angkat orang tua yang mengadopsi. Adopsi tidak bisa dibatalkan oleh siapapun juga.

Tata cara pengangkatan anak diatur juga dalam Pasal 8 sampai 10 Staatsblad 1917 nomor 129, dimana pada Pasal 8 menyebutkan empat syarat untuk pengangkatan anak, yaitu :

1. Persetujuan orang yang mengangkat anak ;

2. Jika anak yang diangkat itu adalah anak sah dari orang tuanya, maka diperlukan izin orang tua itu ; jika bapaknya sudah wafat dan ibu nya sudah kawin lagi, maka harus ada persetujuan dari walinya dan balai harta peninggalan selaku penguasa wali ; dan Jika anak yang akan diangkat itu adalah lahir di luar perkawinan, maka diperlukan izin dari orangtuanya yang mengakui sebagai anaknya, manakala anak itu sama sekali tidak diakui sebagai anak, maka harus ada persetujuan dari walinya serta dari Balai Harta Peninggalan.

3. Jika anak yang akan diangkat itu sudah berusia 19 tahun maka diperlukan pula persetujan ari anak itu sendiri.

4. Manakala yang akan mengangkat anak itu seorang perempuan janda, maka harus ada persetujuan dari saudara laki-laki dan ayah dari almarhum suaminya , atau jika tidak ada saudara laki-laki atau ayah yang masih hidup, atau jika mereka tidak menetap di Indonesia maka harus ada persetujuan dari anggota laki-laki dari keluarga almarhum suaminya dalam garis laki-laki sampai derajat keempat. $^{12}$

Persetujuan yang termaktub dalam syarat diatas dapat diganti dengan suatu izin dari Pengadilan Negeri di wilayah kediaman janda yang ingin mengangkat anak tadi. Menurut Pasal 10, pengangkatan anak ini harus dilakukan dengan akte notaris. Sedang yang menyangkut dengan masalah akibat hukum dari pengangkatan anak itu diatur dalam Pasal 11,12,13,dan 14 Staatsblad 1917 nomor 129. Pasal 11 mengenai nama keluarga orang yang mengangkat anak, nama-nama juga menjadi nama dari anak yang diangkat. Pasal 12, menyamakan seorang anak angkat dengan anak sah dari perkawinan orang yang mengangkat. Pasal 13, mewajibkan balai harta peninggalan untuk apabila ada seorang

${ }^{12}$ Muderis Zaini, $O p$ Cit, hal 35 
janda yang mengangkat anak, mengambil tindakan-tindakan yang perlu guna mengurus dan menyelamatkan barang-barang kekayaan dari anak yang diangkat itu. Pasal 14, suatu pengangkatan anak berakibat putusnya hubungan hukum antara anak yang diangkat dengan orang tua nya sendiri. Pasal 15, suatu pengangkatan anak tidak dapat dibatalkan oleh yang bersangkutan sendiri. Kemudian pengangkatan anak perempuan atau pengangkatan anak secara lain daripada akte notaris, adalah batal dengan sendirinya.

\section{Metode Penelitian}

Jenis penelitian yang digunakan penulis adalah penelitian hukum yuridis norrmatif. Yang dimaksud dengan yuridis normatif adalah penelitian hukum yang meletakkan hukum sebagai sebuah bangunan sistem norma yaitu mengenai asas, norma, kaidah dari peraturan perundang-undangan. Penelitian ini mengacu pada analisa norma hukum tertulis dalam penelitian ini yaitu Undang-undang Nomor 1 Tahun 1974 tentang Perkawinan, Undang-undang Nomor 23 Tahun 2002 tentang Perlindungan Anak dan Peraturan Pelaksana Nomor 54 Tahun 2007 yang merupakan Peraturan Pelaksana dari UU Nomor 23 Tahun 2002 dan peraturan perundang-undangan lainnya.

\section{Pembahasan}

\section{Prosedur Pengangkatan Anak (Adopsi) Berdasarkan Peraturan Perundang- Undangan}

Terkait dengan prosedur pengangkatan anak atau yang biasa disebut dengan adopsi, berdasarkan peraturan perundang-undangan adalah melakukan pengangkatan anak (adopsi) Indonesia yang dilakukan oleh Warga Negara Indonesia (WNI) terdiri dari beberapa jenis (berdasarkan Pedoman Pelaksanaan Pengangkatan Anak terbitan Departemen Sosial Republik Indonesia, Direktorat Jenderal Pelayanan dan Rehabilitasi Sosial Direktorat Bina Pelayanan Sosial Anak, hal 7-17), yaitu:

1. Pengangkatan Anak antar warga negara Indonesia (Domestic Adoption);

2. Pengangkatan Anak secara langsung (Private Adoption);

3. Pengangkatan Anak oleh Orang Tua Tunggal (Single Parent);

4. Pengangkatan Anak menurut Hukum Adat.

Pada penelitian ini, maka pengangkatan anak yang dimaksud adalah pengangkatan anak antar WNI. Untuk Persyaratan dan Prosedur Pengangkatan Anak antar warganegara Indonesia (Domestic Adoption), memiliki beberapa katagori sebagai berikut : 
a. Suami dan Istri Warga Negara Indonesia (WNI); atau

b. Suami WNI, dan Istri Warga Negara Asing (WNA).

Selain itu, Persyaratan Pengangkatan Anak juga diatur dalam Pasal 12 \& Pasal

13 PP No. 54 Tahun 2007 tentang Pelaksanaan Pengangkatan Anak meliputi:

a. Belum berusia 18 (delapan belas) tahun.

b. Merupakan anak terlantar atau ditelantarkan.

c. Berada dalam asuhan keluarga atau dalam lembaga pengasuhan

d. Anak

e. Memerlukan perlindungan khusus.

Usia anak angkat sebagaimana dimaksud di atas meliputi:

a. anak belum berusia 6 (enam) tahun, merupakan prioritas utama

b. anak berusia 6 (enam) tahun sampai dengan belum berusia 12 (dua belas) tahun

c. sepanjang ada alasan mendesak

d. anak berusia 12 (dua belas) tahun sampai dengan belum berusia 18 (delapan belas) tahun, sepanjang anak memerlukan perlindungan khusus.

Calon orang tua angkat harus memenuhi syarat-syarat:

a. sehat jasmani dan rohani.

b. berumur paling rendah 30 (tiga puluh) tahun dan paling tinggi 55 (lima puluh lima) tahun.

c. beragama sama dengan agama calon anak angkat.

d. berkelakuan baik dan tidak pernah dihukum karena melakukan tindak kejahatan.

e. berstatus menikah paling singkat 5 (lima) tahun.

f. tidak merupakan pasangan sejenis.

g. tidak atau belum mempunyai anak atau hanya memiliki satu orang anak.

h. dalam keadaan mampu ekonomi dan sosial.

i. memperoleh persetujuan anak dan izin tertulis orang tua atau wali anak.

j. membuat pernyataan tertulis bahwa pengangkatan anak adalah demi kepentingan terbaik bagi anak, kesejahteraan dan perlindungan anak.

k. adanya laporan sosial dari pekerja sosial setempat. 
1. telah mengasuh calon anak angkat paling singkat 6 (enam) bulan, sejak izin pengasuhan diberikan. dan

m. memperoleh izin Menteri dan/atau kepala instansi sosial.

Sehingga berdasarkan PP No. 54 Tahun 2007 tentang Pelaksanaan Pengangkatan Anak diatas, dapat di gambarkan alur sebagai berikut :

1. Permohonan pengangkatan anak diajukan kepada Instansi Sosial Kabupaten/Kota

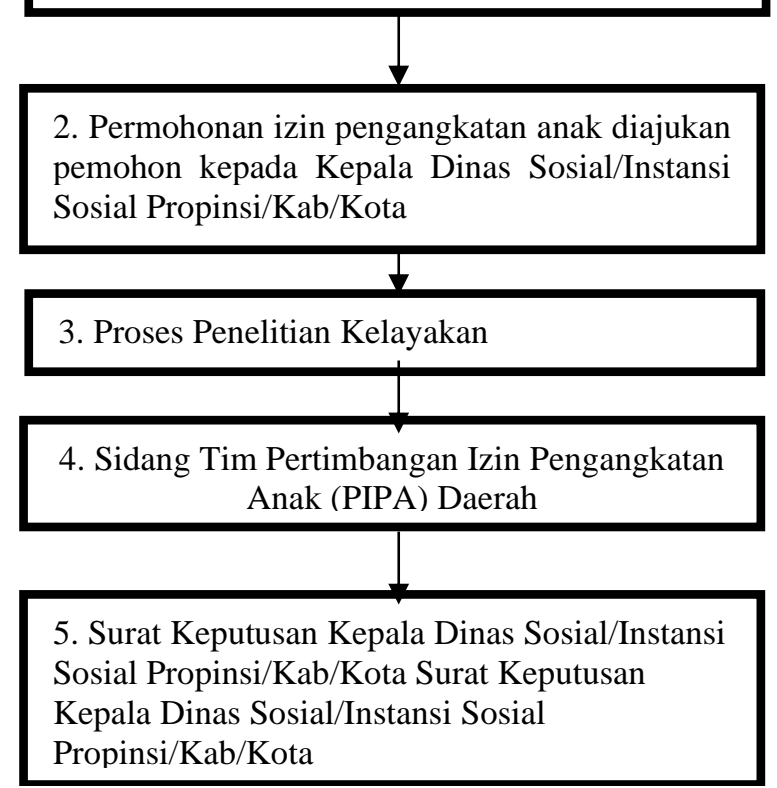

\section{Gambar 1.1. Alur Prosedur Pengangkatan anak}

Pada alur diatas berdasarkan PP No. 54 Tahun 2007 tentang Pelaksanaan Pengangkatan Anak dapat dijelaskan bahwa tahapan pertama kali yang harus dilakukan adalah Permohonan pengangkatan anak diajukan kepada Instansi Sosial Kabupaten/Kota, dengan persyaratan sebagai berikut :

1) Surat penyerahan anak dari orang tua/walinya kepada instansi sosial;

2) Surat penyerahan anak dari Instansi Sosial Propinsi/Kab/Kota kepada Organisasi Sosial (selanjutnya disingkat dengan orsos);

3) Surat penyerahan anak dari orsos kepada calon orang tua angkat;

4) Surat keterangan persetujuan pengangkatan anak dari keluarga suami-istri calon orang tua angkat;

5) Fotokopi surat tanda lahir calon orang tua angkat;

6) Fotokopi surat nikah calon orang tua angkat; 
7) Surat keterangan sehat jasmani berdasarkan keterangan dari Dokter Pemerintah;

8) Surat keterangan sehat secara mental berdasarkan keterangan Dokter Psikiater;

9) Surat keterangan penghasilan dari tempat calon orang tua angkat bekerja.

Kemudian setelah melakukan pengajuan Surat Keputusan Kepala Dinas Sosial/Instansi Sosial Propinsi/Kab/Kota, Permohonan izin pengangkatan anak diajukan pemohon kepada Kepala Dinas Sosial/Instansi Sosial Propinsi/Kab/Kota dengan ketentuan sebagai berikut:

1) Ditulis tangan sendiri oleh pemohon di atas kertas bermeterai cukup;

2) Ditandatangani sendiri oleh pemohon (suami-istri);

3) Mencantumkan nama anak dan asal usul anak yang akan diangkat.

Dalam hal calon anak angkat tersebut sudah berada dalam asuhan keluarga calon orang tua angkat dan tidak berada dalam asuhan organisasi sosial, maka calon orang tua angkat harus dapat membuktikan kelengkapan surat-surat mengenai penyerahan anak dan orang tua/wali keluarganya yang sah kepada calon orang tua angkat yang disahkan oleh instansi social tingkat Kabupaten/Kota setempat, termasuk surat keterangan kepolisian dalam hal latar belakang dan data anak yang diragukan (domisili anak berasal). Kemudian memasuki tahap Proses Penelitian Kelayakan dan Sidang Tim Pertimbangan Izin Pengangkatan Anak (PIPA) Daerah sebelum diterbitkannya Surat Keputusan Kepala Dinas Sosial/Instansi Sosial Propinsi/Kab/Kota bahwa calon orang tua angkat dapat diajukan ke Pengadilan Negeri untuk mendapatkan ketetapan sebagai orang tua angkat. Pengadilan yang dimaksud adalah Pengadilan Negeri tempat anak yang akan diangkat itu berada (berdasarkan Surat Edaran Mahkamah Agung No. 6 Tahun 1983 tentang Penyempurnaan Surat Edaran No.2 Tahun 1979 mengenai Pengangkatan Anak. Pengadilan Agama juga dapat memberikan penetapan anak berdasarkan hukum Islam (berdasarkan Undang-Undang No. 3 Tahun 2006 tentang Peradilan Agama.

Untuk proses pemeriksaan oleh Pengadilan, perlu mempersiapkan sedikitnya dua orang saksi untuk memperkuat permohonan dan meyakinkan Pengadilan bahwa pemohon secara sosial dan ekonomis, moril maupun materiil mampu menjamin kesejahteraan anak yang akan diangkat, kemudian adanya Penetapan Pengadilan dan diberikannya Surat Penetapan Pengadilan terkait hal tersebut. 
Terkait dengan anak yang akan diadopsi, berdasarkan Staatblaad 1917 No. 129, diatur tentang pengangkatan anak yang hanya dimungkinkan untuk anak laki-laki dan hanya dapat dilakukan dengan Akta Notaris. Staatblaad ini mengatur tentang pengangkatan anak bagi orang-orang Tionghoa yang selain memungkinkan pengangkatan anak oleh pemohon yang terikat perkawinan, juga bagi yang pernah terikat perkawinan (duda atau janda). Namun bagi janda yang suaminya telah meninggal dan suami meninggalkan wasiat yang isinya tidak menghendaki pengangkatan anak, maka janda tersebut tidak dapat melakukannya.

Pengangkatan anak menurut Staatblaad ini hanya dimungkinkan untuk anak lakilaki dan hanya dapat dilakukan dengan Akte Notaris. Namun, Yurisprudensi (Putusan Pengadilan Negeri Istimewa Jakarta) tertanggal 29 Mei 1963, telah membolehkan mengangkat anak perempuan. ${ }^{13}$

Tetapi hal tersebut sudah tergantikan sejak adanya surat edaran mahkamah agung tanggal 7 April 1979 No. 2 tahun 1979 tentang Pengangkatan Anak yang menyatakan bahwa pengesahan pengangkatan anak warga negara Indonesia hanya dapat dilakukan dengan suatu penetapan di Pengadilan negeri, dan tidak dibenarkan apabila pengangkatan anak tersebut dilakukan dengan Akta yang dilegalisir oleh Pengadilan negeri. Sehingga dengan demikian, kasus pengangkatan anak harus melalui penetapan Pengadilan negeri.

Sehingga terkait dengan kasus pengakuan anak yang dibahas dalam penulisan ini, maka pengakuan anak yang dilakukan oleh orang tua angkat dan orang tua kandung yang sifatnya privat antar pihak dan tidak melalui perngajuan permohonan lembaga atau dinas sosial, seharusnya didasarkan pada surat edaran mahkamah agung tanggal 7 April 1979 No. 2 tahun 1979 tentang Pengangkatan Anak, yang menjelaskan bahwa pengangkatan anak harus dengan penetapan pengadilan.

\section{E. Penutup}

Berdasarkan teori dan analisa pembahasan terhadap kasus pengangkatan anak atau pada kasus tersebut lebih tepat dengan istilah pengakuan anak, maka dapat disimpulkan bahwa Pada dasarnya pengangkatan anak harus dengan penetapan Pengadilan, hal tersebut didasarkan pada surat edaran mahkamah agung tanggal 7 April 1979 No. 2 tahun

\footnotetext{
${ }^{13}$ artikel Adopsi Anak oleh Lembaga Bantuan Hukum APIK
} 
1979 tentang Pengangkatan Anak dikatakan antara lain bahwa pengesahan pengangkatan anak warga negara Indonesia hanya dapat dilakukan dengan suatu penetapan di Pengadilan negeri, dan tidak dibenarkan apabila pengangkatan anak tersebut dilakukan dengan Akta yang dilegalisir oleh Pengadilan negeri.

Kasus pengangkatan anak harus melalui penetapan Pengadilan negeri dan Akta yang dibuat dihadapan notaris terkait dengan pengakuan anak hanya bersifat pengikatan terhadap apa yang dikehendaki para pihak secara privat terkait hubungan hukum masingmasing pihak tersebut terhadap pengangkatan anak dan tidak memiliki kekuatan hukum mutlak terkait dengan legalitas status pengangkatan anak tersebut jika tidak didaftarkan dan mendapat penetapan Pengadilan negeri.

\section{DAFTAR PUSTAKA}

\section{A. Buku :}

Abdulkadir Muhammad, Hukum Perdata Indonesia, PT. Citra Aditya Bakti, Bandung, 2010 Ahmadi Miru, Hukum Perikatan, Rajawali Pers, Jakarta, 2013

A. Plito, Pembuktian Dan Daluwarsa, PT. Intermasa, Jakarta, 1986

Djaja.S.Meliala, Pengangkatan Anak (Adopsi) Di Indonesia, Tarsito, Bandung, 1982

Dzulkifli dan Ustman, Kamus Hukum, Quantum Media Pers, Jakarta, 2010

Kartini Muljani Dan Gunawan Widjaja, Perikatan Yang Lahir Dari Perjanjian, Rajawali Pers, Jakarta, 2010

Lulik Djatikumoro, Hukum Pengangkatan Anak Di Indonesia, PT. Citra Aditya Bakti, Bandung, 2011

Muderis Zaini, Adopsi Suatu Tinjauan Dari Tiga Sistem Hukum, Sinar Grafika, Jakarta, 2006

Peter Mahmud Marzuki, Penelitian Hukum, Kencana, Jakarta, 2011

R, Soeroso, Perjanjian Di Bawah Tangan, Sinar Grafika, Jakarta, 2010

Rusli Pandika, Hukum Pengangkatan Anak, Sinar Grafika, Jakarta, 2012

Sjaifurrachman, Aspek Pertanggung Jawaban Notaris Dalam Pembuatan Akta, CV. Mandar Maju, Bandung, 2011

Subekti, Hukum Perjanjian, PT. Intermasa, Jakarta, 2002

Subekti, Pokok-Pokok Hukum Perdata, PT. Intermasa, Jakarta, 1980

Sudikno Mertokusumo, Mengenal Hukum Suatu Pengantar, Liberty, Yogyakarta, 1999

Viktor M. Situmorang dan Cormentyna Sitanggang, Gross Akta Dalam Pembuktian Dan Eksekusi, Rinika Cipta, Jakarta, 1993

\section{B. Peraturan Perundang-Undangan :}

Undang-Undang Dasar 1945

Kitab Undang-Undang Hukum Perdata.

Undang-Undang Nomor 1 Tahun 1974 Tentang Perkawinan.

Undang-Undang Nomor 23 Tahun 2002 Tentang Perlindungan Anak

Undang-Undang Nomor 4 Tahun 1979 Tentang Kesejahteraan Anak

Undang-Undang Nomor 30 Tahun 2004 Tentang Jabatan Notaris 
Staatsblad 1917 Nomor 129 Tentang Ketentuan-Ketentuan Untuk Seluruh Indonesia Tentang Hukum Perdata Dan Hukum Dagang

PP Nomor 54 Tahun 2007 Tentang Peraturan Pelaksana Undang-Undang Nomor 23

Tahun 2002 Tentang Perlindungan Anak

SEMA RI Nomor 6 Tahun 1983 Tentang Penyempurnaan SEMA RI Nomor 2 Tahun 1979 Mengenai Pengangkatan Anak 